\title{
SARS-CoV-2 assessment of non-healthcare workers: The potential role of work safety recommendations
}

\section{Type}

Research paper

\section{Keywords}

occupational health, COVID-19, preventative medicine

\begin{abstract}
Introduction

Recommendations have been issued to prevent workplace-related SARS-CoV-2 outbreaks. To discuss their impact, we assessed non-healthcare workers of a company which implemented such recommendations from early on.

Material and methods

We performed molecular and serological tests to SARS-CoV-2 in workers of a Portuguese electrical company, in June 2020. Workers were also subject to an epidemiological survey.
\end{abstract}

Results

A total of 1359 workers (out of 5850) underwent SARS-CoV-2 testing and answered the survey. Twenty-five participants $(1.8 \%)$ had positive testing results.

Conclusions

We observed low frequency of SARS-CoV-2 infection in a company that early on implemented policies to decrease COVID-19 risk. 


\section{Abstract}

Introduction: Recommendations have been issued to prevent workplace-related SARS-CoV2 outbreaks. To discuss their impact, we assessed non-healthcare workers of a company which implemented such recommendations from early on.

Material and methods: We performed molecular and serological tests to SARS-CoV-2 in workers of a Portuguese electrical company, in June 2020. Workers were also subject to an epidemiological survey.

Results: A total of 1359 (out of 5850) workers underwent SARS-CoV-2 testing and answered the survey. Twenty-five participants $(1.8 \%)$ had positive testing results.

Conclusions: We observed low frequency of SARS-CoV-2 infection in a company that early on implemented policies to decrease COVID-19 risk. 


\section{Introduction}

Since its beginning, the COVID-19 pandemic has directly resulted in more than two million deaths worldwide ${ }^{1}$. According to the European Centre for Disease Prevention and Control, between March and July 2020, 1376 clusters of COVD-19 have been reported in occupational settings in 16 European countries, of which 540 were non-healthcare related ${ }^{2}$. In fact, the possibility of COVID-19 outbreaks associated with occupational settings has prompted governments, health agencies and employers to issue recommendations aimed at increasing safety at the workplace ${ }^{3-5}$. The latter include the use of personal protection equipment by workers, routine (at least more than once per day) cleaning of frequently touched surfaces, the provision of adequate ventilation (with recommendations ranging from leaving doors and windows opened whenever possible to installation of high-efficiency particulate air filtration or ultraviolet germicidal irradiation systems), the limitation of contact between workers, and the (at least partial) adoption of remote working ${ }^{3-7}$. With the aim of discussing the impact of these protective measures, we herein report the results of molecular and serological tests to SARS-CoV-2 performed along an epidemiological survey in workers of an electrical utility company.

\section{Material and Methods}

Molecular (polymerase chain reaction - PCR) and serological (Immunoglobulin G - IgG) tests to SARS-CoV-2 were performed in 3163 out of 5850 workers of EDP-Energias de Portugal (selected as it is the largest electrical utility company in Portugal, and on account of its early adoption of protective measures in the context of SARS-CoV-2), in June 2020

(Supplementary Figure 1). For each participant, molecular and serological tests were performed on the same day. Molecular tests were performed with Allplex ${ }^{\mathrm{TM}}$ SARS-CoV-2 Assay (Seegene Inc, Seoul, South Korea), whose sensitivity and specificity are close to $100 \%$ 
(as displayed in https://www.finddx.org/covid-19/sarscov2-eval-molecular/). Serological tests were performed with Euroimmun SARS-CoV-2 ELISA tests (Euroimmun AG, Lübeck, Germany), which have a sensitivity of $90 \%$ and a specificity close to $100 \%$ (as displayed in https://www.fda.gov/medical-devices/coronavirus-disease-2019-covid-19-emergency-useauthorizations-medical-devices/eua-authorized-serology-test-performance).

In the subsequent month, an electronic epidemiological survey - assessing participant demographic characteristics, clinical comorbidities, medication use, risk exposure (including that related to the workplace), and performance (and results) of previous tests to SARS-CoV2 (Supplementary Digital Material 1: Supplementary Survey) - was sent by e-mail to all tested workers, with the first mail being sent on July 13, 2020, and two additional reminders each sent one week apart. The survey was purposely-developed by the authors of this study based on the most relevant epidemiological variables known at that time. On account of the low number of positive testing results, only descriptive analyses were performed.

This study has been approved by the Ethics Committee of the Fundação D. Anna de Sommer Champalimaud e Dr. Carlos Montez Champalimaud (Ethics approval number 15, dated of April 26, 2020). All participants gave informed consent prior to participation in this study. Testing was voluntary and costs were supported by the company.

\section{Results}

A total of 1359 workers answered the epidemiological survey, corresponding to $43.0 \%$ of those who were sent that questionnaire (Supplementary Figure 1). Demographic variables had similar distributions among those workers who answered and who did not answer the epidemiological survey. Most participants were males (84.0\%) and only one-third reported at least one comorbidity (Table I). More than two-thirds of participants $(84.4 \%)$ worked from 
home for at least one week (median number of weeks working from home=15). Only 19.3\% of participants reported never using a mask when working.

A total of 25 participants (1.8\%) had positive molecular and/or serological results (Table II) 14 participants had positive molecular results, while 17 patients had positive serological results, with 6 patients having positive results to both types of tests. Of those patients with positive molecular results, nine concerned PCR tests performed one or more months before our study began (in June 2020) - among them, only five had positive serological results. Eleven of those 25 patients reported comorbidities (the most frequent being hypertension), and nine reported taking regular medication for chronic diseases. Six patients reported not wearing a mask during work, while four did not work from home in any week; other potential risk factors (e.g., close contact with a patient with SARS-CoV-2 infection, or travel abroad) were reported by just over a quarter of the patients $(n=7)$. Less than half of the patients $(12$ out of 25) reported any symptom compatible with COVID-19 infection during the year of 2020.

\section{Discussion}

Overall, only a small percentage of the assessed workers (1.8\%) had results compatible with infection to SARS-CoV-2. This value is lower than the one obtained in a serological survey applied between May and July to the general Portuguese population $(2.9 \%)^{8}$. In part, this may be explained by the early adoption (namely in February 2020) of several policies, which include remote and shift work schemes, provision of masks and disinfectant products in the workplace, space reorganization and implementation of access restrictions, regular workspace cleaning, implementation of a medical hotline which monitored suspected and confirmed cases of SARS-CoV-2 infection, and celebration of protocols with laboratories so that molecular and serological tests could be regularly performed to workers who were not 
working remotely (Supplementary Figure 2 for a timeline of policies). Taken together, these measures may have allowed for reduction of contacts among workers, and reduction of infection risk associated with each contact (as individual protection equipment was used and confirmed were early identified).

In this study, the frequency of current or past COVID-19 infection was assessed by means of molecular and serological tests. The latter are based on the quantification of antibodies to SARS-CoV-2, with IgM antibodies falling quickly within the first weeks post-infection (frequently becoming undetectable after six weeks after symptom onset ${ }^{9}$ ), and $\operatorname{IgG}$ antibodies persisting for a longer period of time. While, a systematic review has suggested that $\operatorname{IgG}$ titres start to decline after eight weeks post-onset, the period during when such antibodies remain detectable is still subject to research ${ }^{9}$. In fact, disappearance and persistence of $\operatorname{IgG}$ antibodies at the $12^{\text {th }}$ week post-disease onset have both been described ${ }^{10-11}$. If disappearance happens to be the most common scenario, then the real frequency of SARS-CoV-2 infections in this study may have been underestimated, particularly concerning earlier infections. Further studies are, thus, required to assess IgG dynamics in the long-term.

In addition, other limitations are worth noting. Firstly, less than half of the workers answered the epidemiological survey, possibly resulting in selection bias. In fact, it is possible to hypothesise that those who answered the survey are more concerned about the COVID-19 pandemic, being also more careful with their own behaviours. Nevertheless, of all 4104 workers of that company undergoing serological testing, only a total of 66 had positive results, corresponding to a seroprevalence of $1.6 \%$ (close to the value observed for those workers answering the questionnaire). Another limitation concerns the possibility of information biases - as the survey was filled by the workers themselves, errors in question interpretation or in the introduction of responses may ensue. Misclassification may also stem from incorrect test results, particularly false negative results with serological tests, whose 
reported sensitivity is of $90 \%{ }^{12}$ ). Finally, the low number of participants with positive PCR and/or serological results only allowed the performance of descriptive analyses.

\section{Recommendations and conclusions}

In conclusion, we observed low frequency of positive PCR and/or serological tests to SARSCoV-2 in an electrical utility company that early on implemented policies to decrease the risk of COVID-19 spread in occupational settings. Such policies include the early adoption of remote and shift work schemes, the provision of individual protection equipment, the provision of medical monitoring, and regular testing of workers. The adoption of such policies may, thus, be recommended in order to increase safety in the workplace.

Keywords: COVID-19; occupational health; preventative medicine 


\section{References}

1. COVID-19 situation update worldwide [Internet]. The European Centre for Disease Prevention and Control; 2021. [cited 2021 Feb 19]. Available from: https://www.ecdc.europa.eu/en/geographical-distribution-2019-ncov-cases

2. The European Centre for Disease Prevention and Control. COVID-19 clusters and outbreaks in occupational settings in the EU/EEA and the UK. Stockholm: ECDC; 2020.

3. Working safely during coronavirus (COVID-19) [Internet]. United Kingdom Government - Department for Business, Energy \& Industrial Strategy and Department for Digital, Culture, Media \& Sport; 2020 [cited 2020 Sep 28]. Available from: https://www.gov.uk/guidance/working-safely-during-coronavirus-covid-19

4. Guidance for Businesses \& Employers - Plan, Prepare and Respond to Coronavirus Disease 2019 [Internet]. Centers for Disease Control and Prevention; 2020. [cited 2020 Sep 28]. Available from: https://www.cdc.gov/coronavirus/2019ncov/community/guidance-business-response.html

5. COVID-19: Back to the workplace - Adapting workplaces and protecting workers [Internet]. European Agency for Safety and Health at Work; 2020. [cited 2020 Sep 28]. Available from: https://oshwiki.eu/wiki/COVID-19:_Back_to_the_workplace__Adapting_workplaces_and_protecting_workers\#Minimising_exposure_to_COVID19_at_work

6. Ventilation in Buildings [Internet]. Centers for Disease Control and Prevention; 2021. [cited 2021 Feb 19]. Available from: https://www.cdc.gov/coronavirus/2019ncov/community/ventilation.html

7. COVID-19: cleaning in non-healthcare settings outside the home [Internet]. Public Health England; 2020. [cited 2021 Feb 19]. Available from: 
https://www.gov.uk/government/publications/covid-19-decontamination-in-nonhealthcare-settings/covid-19-decontamination-in-non-healthcare-settings

8. Instituto Nacional Dr. Ricardo Jorge. Inquérito Serológico Nacional COVID-19 Resultado de apresentação dos resultados preliminares do primeiro inquérito serológico nacional COVID-19 [National Serological Survey COVID-19Preliminary results of the first national serological survey to COVID-19]. Lisbon; 2020.

9. Post N, Eddy D, Huntley C, et al. Antibody response to SARS-CoV-2 infection in humans: A systematic review. PLoS One 2020; 15(12):e0244126.

10. Liu A, Wang W, Zhao X, et al. Disappearance of antibodies to SARS-CoV-2 in a COVID-19 patient after recovery. Clin Microbiol Infect 2020;26(12):1703-1705.

11. Li K, Wu M, Huang B, et al. The Dynamic Changes of Antibodies against SARSCoV-2 during the Infection and Recovery of COVID-19. medRxiv 2020; https://doi.org/10.1101/2020.05.18.20105155.

12. Swadźba J, Bednarczyk M, Anyszek T, Martin E. A comparison of 7 commercial anti-SARS-CoV-2 antibody immunoassays. Arch Med Sci 2020; https://doi.org/10.5114/aoms.2020.98361. 


\section{Supplementary material}

Supplementary Figure 1. Flow chart of study participants selection.

Supplementary Figure 2. Timeline of adopted pandemic management policies 
Table I. Demographic and clinical characteristics of assessed participants

\begin{tabular}{|c|c|}
\hline Variable & $\begin{array}{c}\text { All } \\
\text { participants } \\
(N=\mathbf{1 3 5 9})\end{array}$ \\
\hline Males $-n(\%)$ & $1141(84.0)$ \\
\hline \multicolumn{2}{|l|}{ Age group $-n(\%)$} \\
\hline$<30$ years old & $198(14.6)$ \\
\hline 30-39 years old & $309(22.7)$ \\
\hline 40-49 years old & $300(22.1)$ \\
\hline $50-59$ years old & $338(24.9)$ \\
\hline$\geq 60$ years old & $215(15.7)$ \\
\hline Healthcare professionals $-n(\%)$ & $15(1.1)$ \\
\hline Cohabitants of healthcare professionals $-n(\%)$ & $140(10.3)$ \\
\hline Comorbidities $-n(\%)$ & $464(34.1)^{\mathrm{a}}$ \\
\hline Hypertension & $174(12.8)$ \\
\hline Overweight and obesity & $135(9.9)$ \\
\hline Dyslipidaemia & $15(1.1)$ \\
\hline Heart failure & $8(0.6)$ \\
\hline Other cardiovascular diseases & $24(1.8)$ \\
\hline Diabetes & $33(2.4)$ \\
\hline Thyroid diseases & $8(0.6)$ \\
\hline Asthma & $53(3.9)$ \\
\hline Chronic obstructive pulmonary disease & $3(0.2)$ \\
\hline Other respiratory and allergic diseases & $81(6.0)$ \\
\hline Gastro-intestinal diseases & $9(0.7)$ \\
\hline Kidney diseases & $3(0.2)$ \\
\hline Neuropsychiatric diseases & $12(0.9)$ \\
\hline Auto-immune diseases & $30(2.2)$ \\
\hline Oncological diseases & $8(0.6)$ \\
\hline Other diseases & $31(2.3)$ \\
\hline Regular medication for chronic diseases $-n(\%)$ & $385(28.3)^{\mathrm{b}}$ \\
\hline Antihypertensives & $166(12.3)$ \\
\hline Antidyslipidaemics & $105(7.8)$ \\
\hline Anticoagulants and antithrombotics & $34(2.5)$ \\
\hline Other agents primarily affecting the cardiovascular system & $13(1.0)$ \\
\hline Antidiabetic drugs & $27(2.0)$ \\
\hline Other agents primarily affecting the endocrine system & $31(2.3)$ \\
\hline Antihistamines & $29(2.1)$ \\
\hline Antiasthmatics and bronchodilators & $15(1.1)$ \\
\hline Agents primarily affecting the gastrointestinal system & $40(2.9)$ \\
\hline Agents primarily affecting the genitourinary system & $14(1.0)$ \\
\hline Sedatives and hypnotics & $23(1.7)$ \\
\hline Antidepressants & $17(1.3)$ \\
\hline Other agents primarily affecting the central nervous system & $14(1.0)$ \\
\hline Nonsteroidal anti-inflammatory drugs & $41(3.0)$ \\
\hline Acetaminophen and other analgesics & $42(3.1)$ \\
\hline
\end{tabular}




\begin{tabular}{|c|c|}
\hline Drugs for arthrosis or gout & $21(1.6)$ \\
\hline \multicolumn{2}{|l|}{ Vaccination history $-n(\%)$} \\
\hline Bacillus Calmette-Guérin (BCG) vaccine & $845(62.2)$ \\
\hline Influenza vaccine & $103(7.6)$ \\
\hline Pneumococcus vaccine & $20(1.5)$ \\
\hline Work from home $-n(\%)$ & $1147(84.4)$ \\
\hline Number of weeks working from home - median (p25-p75) & $15(8-17)$ \\
\hline Mask use when working $-n(\%)$ & $1097(80.7)^{\mathrm{c}}$ \\
\hline Since $>\mathbf{3}$ months before testing & $39(3.6)$ \\
\hline Since 3 months before testing & $457(41.7)$ \\
\hline Since 2 months before testing & $187(17.0)$ \\
\hline Since 1 month before testing & $414(37.7)$ \\
\hline$N$ times per day washing hands with soap and water - median (p25-p75) & $10(5-12)$ \\
\hline$N$ times per day disinfecting hands with alcohol-based sanitizers - median (p25-p75) & $8(4-12)$ \\
\hline Symptoms in the 4 weeks before testing $-n(\%)$ & $51(3.8)^{\mathrm{d}}$ \\
\hline Cough & $15(1.1)$ \\
\hline Fever & $9(0.7)$ \\
\hline Dyspnoea & $5(0.4)$ \\
\hline Anosmia & $2(0.1)$ \\
\hline Pharyngitis & $15(1.1)$ \\
\hline Headache & $15(1.1)$ \\
\hline Myalgia & $13(1.0)$ \\
\hline Diarrhoea & $7(0.5)$ \\
\hline Contact with patients with COVID-19-n(\%) & $36(2.6)$ \\
\hline Symptomatic patients & $17(47.2)$ \\
\hline $\begin{array}{l}\text { Contact with other patients with fever, cough, dyspnoea or other COVID-19 } \\
\text { compatible symptoms }-n(\%)\end{array}$ & $18(1.3)$ \\
\hline Travels abroad during $2020-n(\%)$ & $207(15.2)$ \\
\hline $\begin{array}{l}\text { p25: Percentile } 25 ; \text { p75: Percentile } 75 ;{ }^{\text {a }} \text { Including } 341 \text { participants }(73.5 \%) \text { with a single como } \\
\text { participants }(19.8 \%) \text { with two comorbidities, and } 31 \text { participants }(6.7 \%) \text { with more than two com } \\
\text { Including } 220 \text { participants }(57.1 \%) \text { whose outpatient medication belonged to a single drug class, } 73 \\
(19.0 \%) \text { whose outpatient medication belonged to two different classes, and } 165 \text { participants }(42 . \\
\text { outpatient medication belonged to more than two different classes; }{ }^{\mathrm{c}} \text { Including } 91 \%(n=193) \text { particip } \\
\text { those who did never work from home; }{ }^{\mathrm{d}} \text { Including } 36 \text { participants }(71 \%) \text { reporting one single sympt } \\
\text { participants }(29 \%) \text { with more than one symptom. }\end{array}$ & $\begin{array}{l}\text { idity, } 92 \\
\text { idities; } \\
\text { rticipants } \\
\text { t) whose } \\
\text { ts among } \\
\text { n, and } 15\end{array}$ \\
\hline
\end{tabular}


Table II. Description of patients with positive molecular (polymerase chain reaction - PCR) and/or serological results (IgG)

\begin{tabular}{|c|c|c|c|c|c|c|c|c|c|c|c|c|}
\hline Case & Sex & Age group & $\begin{array}{l}\text { Professional } \\
\text { activity }\end{array}$ & Comorbidities & $\begin{array}{c}\text { Regular } \\
\text { medication for } \\
\text { chronic diseases }\end{array}$ & $\begin{array}{c}N \text { months } \\
\text { using mask } \\
\text { when } \\
\text { working } \\
\end{array}$ & $\begin{array}{c}N \text { weeks } \\
\text { working } \\
\text { from } \\
\text { home } \\
\end{array}$ & $\begin{array}{c}\text { COVID-19- } \\
\text { compatible } \\
\text { symptoms } \\
\text { during } 2020 \\
\end{array}$ & $\begin{array}{c}\text { Potential risk } \\
\text { exposures during } \\
2020\end{array}$ & $\begin{array}{l}\text { COVID- } \\
19 \text { related } \\
\text { admission }\end{array}$ & PCR & IgG \\
\hline 1 & Female & 40-44 у.о. & Engineer & $\begin{array}{l}\text { Allergic } \\
\text { diseases }\end{array}$ & None & 1 & 18 & $\begin{array}{l}\text { Yes (March; } \\
\text { June) }\end{array}$ & Travel abroad (France) & No & $+{ }^{a}$ & + \\
\hline 2 & Female & 50-54 у.о. & $\begin{array}{l}\text { Administrative } \\
\text { technician }\end{array}$ & None & $\begin{array}{l}\text { Antiacid/antiulcer } \\
\text { agents }\end{array}$ & 0 & 16 & Yes (March) & No & No & $+{ }^{a}$ & + \\
\hline 3 & Male & 65-69 у.о. & Engineer & None & $\begin{array}{l}\text { Antihypertensives; } \\
\text { antidyslipidaemics }\end{array}$ & 1 & 8 & Yes (March) & No & Yes $^{b}$ & $+{ }^{a}$ & + \\
\hline 4 & Male & 65-59 у.о. & $\begin{array}{l}\text { Executive } \\
\text { manager }\end{array}$ & Hypertension & $\begin{array}{l}\text { Antihypertensives; } \\
\text { antidyslipidaemics; } \\
\text { anticoagulants/ } \\
\text { antithrombotics; } \\
\text { antiacid/antiulcer } \\
\text { agents }\end{array}$ & 1 & 10 & $\begin{array}{l}\text { Yes (March; } \\
\text { June) }\end{array}$ & Travel abroad (France) & No & $++^{a}$ & + \\
\hline 5 & Male & 25-29 у.о. & Engineer & None & None & 2 & 6 & No & Travel abroad (Italy) & No & $+^{c}$ & - \\
\hline 6 & Male & $40-44$ у.о. & Manager & None & None & 2 & 4 & No & No & No & $++^{c}$ & - \\
\hline 7 & Male & 60-64 у.о. & Engineer & $\begin{array}{l}\text { Hypertension; } \\
\text { overweight }\end{array}$ & $\begin{array}{l}\text { Antihypertensives; } \\
\text { antiacid/antiulcer } \\
\text { agents }\end{array}$ & 0 & 17 & No & No & No & $+^{c}$ & - \\
\hline 8 & Male & 35-39 у.о. & $\begin{array}{l}\text { Production } \\
\text { supervisor }\end{array}$ & None & None & 3 & 8 & No & No & No & $+^{\mathrm{d}}$ & - \\
\hline 9 & Male & 60-64 у.о. & Electrician & $\begin{array}{l}\text { Unspecific } \\
\text { systemic } \\
\text { symptoms }\end{array}$ & None & 2 & 0 & Yes (March) & No & No & $+{ }^{\mathrm{d}}$ & + \\
\hline 10 & Male & $20-24$ y.o. & Electrician & None & None & 3 & 8 & Yes & $\begin{array}{l}\text { Family contact with a } \\
\text { patient with confirmed } \\
\text { COVID-19 infection }\end{array}$ & No & $+^{e}$ & + \\
\hline 11 & Male & $25-29$ у.о. & Electrician & None & None & 3 & 8 & No & No & No & $++^{e}$ & - \\
\hline 12 & Male & 35-39 у.о. & Electrician & None & $\begin{array}{l}\text { Acetaminophen; } \\
\text { non-steroidal anti- } \\
\text { inflammatory drugs }\end{array}$ & 1 & 12 & No & $\begin{array}{c}\text { Cohabitant with a } \\
\text { healthcare professional }\end{array}$ & No & $++^{e}$ & - \\
\hline 13 & Male & $50-54$ у.о. & Electrician & None & None & 3 & 0 & No & No & No & $+{ }^{e}$ & - \\
\hline 14 & Male & $55-59$ у.о. & Engineer & Hypertension & Antihypertensives & 0 & 17 & No & No & No & $++^{e}$ & - \\
\hline 15 & Male & $35-39$ у.о. & Engineer & None & None & 0 & 18 & Yes (January) & No & No & $-e$ & + \\
\hline
\end{tabular}




\begin{tabular}{|c|c|c|c|c|c|c|c|c|c|c|c|c|}
\hline 16 & Male & 30-34 у.о. & $\begin{array}{l}\text { Maintenance } \\
\text { technician }\end{array}$ & None & None & 2 & 10 & Yes (March) & Travel abroad (Spain) & No & $-\mathrm{e}$ & + \\
\hline 17 & Male & 40-44 у.о. & Engineer & None & None & 1 & 15 & No & No & No & $-e$ & + \\
\hline 18 & Female & $40-44$ y.o. & Architect & Bronchiectasis & None & 2 & 19 & Yes (March) & No & No & $-e$ & + \\
\hline 19 & Female & 45-49 у.о. & $\begin{array}{l}\text { Communication } \\
\text { worker }\end{array}$ & Asthma & $\begin{array}{l}\text { Acetaminophen; } \\
\text { anti-asthmatics }\end{array}$ & 1 & 18 & Yes (March) & No & No & $-e$ & + \\
\hline 20 & Male & $50-54$ у.о. & Engineer & Sleep apnoea & None & 0 & 12 & No & No & No & $-\mathrm{e}$ & + \\
\hline 21 & Male & $50-54$ у.о. & Electrician & None & None & 3 & 0 & No & No & No & $-\mathrm{e}$ & + \\
\hline 22 & Male & $55-59$ у.о. & $\begin{array}{l}\text { Maintenance } \\
\text { technician }\end{array}$ & $\begin{array}{c}\text { Hypertension, } \\
\text { overweight }\end{array}$ & Antihypertensives & 3 & 8 & Yes (January) & No & No & $-\mathrm{e}$ & + \\
\hline 23 & Male & $55-59$ у.о. & Electrician & None & None & 3 & 11 & No & No & No & $-\mathrm{e}$ & + \\
\hline 24 & Female & 60-64 у.о. & Nurse & $\begin{array}{c}\text { Hypertension; } \\
\text { overweight }\end{array}$ & Antihypertensives & 3 & 0 & Yes & Healthcare professional & No & $-\mathrm{e}$ & + \\
\hline 25 & Male & 60-64 у.о. & Topographer & $\begin{array}{l}\text { Non-specified } \\
\text { chronic } \\
\text { respiratory } \\
\text { diseases } \\
\end{array}$ & Antihistamine & 0 & & No & No & No & $-\mathrm{e}$ & + \\
\hline
\end{tabular}

${ }^{a}$ Results concerning a PCR test performed three months before this study was conducted (March 2020); ${ }^{\mathrm{b}}$ Including admission in intensive care unit; ${ }^{\mathrm{c}}$ Results concerning a PCR test performed two months before this study was conducted (April 2020); ${ }^{\mathrm{d}}$ Results concerning a PCR test performed one month before this study was conducted (May 2020); ${ }^{\mathrm{e}}$ PCR performed within the context of this study (June 2020). 


\section{Supplementary Digital Material 1: Supplementary survey}

\section{Epidemiological survey answered by the participants of this study}

[Below, we list the questions displayed in the epidemiological survey answered by the participants of this study. Such questions were presented after a preamble and after participants gave informed consent for their participation in this study]

1. Date:

2. Name:

3. Company number:

4. City:

5. Sex: O Male $\bigcirc$ Female

6. Age group: $\bigcirc$ Less than 20 years old $\bigcirc$ 20-24 years old $\bigcirc$ 25-29 years old $\bigcirc$ 30-34 years old $\bigcirc$ 35-39 years old $\bigcirc$ 40-44 years old $\bigcirc$ 45-49 years old $\bigcirc$ 50-54 years old $\bigcirc$ 55-59 years old $\bigcirc$ 60-64 years old $\bigcirc$ 65-69 years old $\bigcirc 70$ years old or more

7. Occupation:

8. Are you a healthcare professional? $\bigcirc$ Yes $\bigcirc$ No

a. Indicate the service where you work*

b. Indicate your occupation*: $\bigcirc$ Doctor $\bigcirc$ Nurse $\bigcirc$ Technician $\bigcirc$ Other

9. Do you live with a healthcare professional? $\bigcirc$ Yes $\bigcirc$ No

10. Do you wear a mask in your professional activity? $\bigcirc$ Yes $\bigcirc$ No

a. Since when*? O Since before March $O$ Since March $\bigcirc$ Since April $\bigcirc$ Since May

11. How many times per day do you wash your hands with soap and water?

12. How many times per day do you disinfect your hands with a alcohol-based sanitizer?

13. Did you work from home for at least some time? $\bigcirc$ Yes $\bigcirc$ No

a. For how many weeks did you work from home*?

b. When did you start working from home*?
I -

14. In the 2 weeks prior to being tested you had (select all that apply): $\square$ Fever $\square$ Cough Shortness of breath $\square$ Sore throat $\square$ Muscle pain $\square$ Headache $\square$ Smell loss $\square$ Diarrhoea $\square$ No complaints

15. In the 2-4 weeks prior to being tested you had (select all that apply): $\square$ Fever $\square$ Cough Shortness of breath $\square$ Sore throat $\square$ Muscle pain $\square$ Headache $\square$ Smell loss $\square$ Diarrhoea $\square$ No complaints

16. Did you experience any symptom compatible with COVID-19 infection (fever, cough, shortness of breath, sore throat, muscle pain, headache, smell loss or diarrhoea)? ○ Yes $\bigcirc$ No

a. The symptoms were experienced in*: $\bigcirc$ March $2020 \bigcirc$ February $2020 \bigcirc$ January 2020 O December 2019 O November 2019 O Before November 2019

17. Have you undergone any other COVID-19 test with a nasopharyngeal swab? $\bigcirc$ Yes $\bigcirc$ No 
a. When were you tested*?

b. What was the test result*? $\bigcirc$ Positive $\bigcirc$ Negative

18. Have you recently been hospitalized? $\bigcirc$ Yes $\bigcirc$ No

a. Have you been admitted to an intensive care unit*? $\bigcirc$ Yes $\bigcirc$ No

19. Before being tested, were you in contact with any patient with COVID-19? O Yes O No

a. When did such contact occur*? $\bigcirc$ Within 2 weeks before testing $\bigcirc$ Between 2 and 4 weeks before testing $O$ More than 4 weeks before testing

b. Was the patient with whom you had contact symptomatic*? $\bigcirc$ Yes $\bigcirc$ No

c. In what context did that contact occur*? $\bigcirc$ Professional $\bigcirc$ Familiar $\bigcirc$ Other (e.g., leisure, civic, religious...) $\bigcirc$ Unknown

20. In the month before testing, did you contact with anyone else who was sick (with fever, cough, or shortness of breath)? O Yes $\bigcirc$ No

a. When did such contact occur*? $\bigcirc$ Within 2 weeks before testing $\bigcirc$ Between 2 and 4 weeks before testing

21. Since the beginning of 2020 , did you travel abroad? O Yes $O$ No

a. Did you travel abroad in the 2 weeks prior to being tested*? $\bigcirc$ Yes $\bigcirc$ No

i. To which place(s)?

b. Did you travel abroad in the 3-4 weeks prior to being tested? $\bigcirc$ Yes $\bigcirc$ No

i. To which place(s)?

c. Did you travel abroad more than 4 weeks prior to being tested? $\bigcirc$ Yes $\bigcirc$ No

i. To which place(s)?

22. Do you have any of these diseases? (select all that apply): $\square$ Asthma $\square$ Chronic obstructive pulmonary disease $\square$ Other chronic respiratory diseases $\square$ Hypertension (high blood pressure) $\square$ Heart failure $\square$ Other cardiovascular diseases $\square$ Diabetes $\square$ Chronic kidney disease $\square$ Chronic liver disease $\square$ HIV $\square$ Oncological diseases $\square$ Autoimmune diseases $\square$ Overweight/obesity $\square$ Others (indicate which:

23. Are you undergoing haemodialysis? $\bigcirc$ Yes $\bigcirc$ No

24. Did you get the BCG vaccine? O Yes $\bigcirc$ No

25. Did you get the flu vaccine? $\bigcirc$ Yes $\bigcirc$ No

26. Did you get the pneumonia vaccine? $\bigcirc$ Yes $\bigcirc$ No

27. What medication do you do for chronic diseases?

* Question presented only if an affirmative answer was provided to the question here displayed at an upper level. 


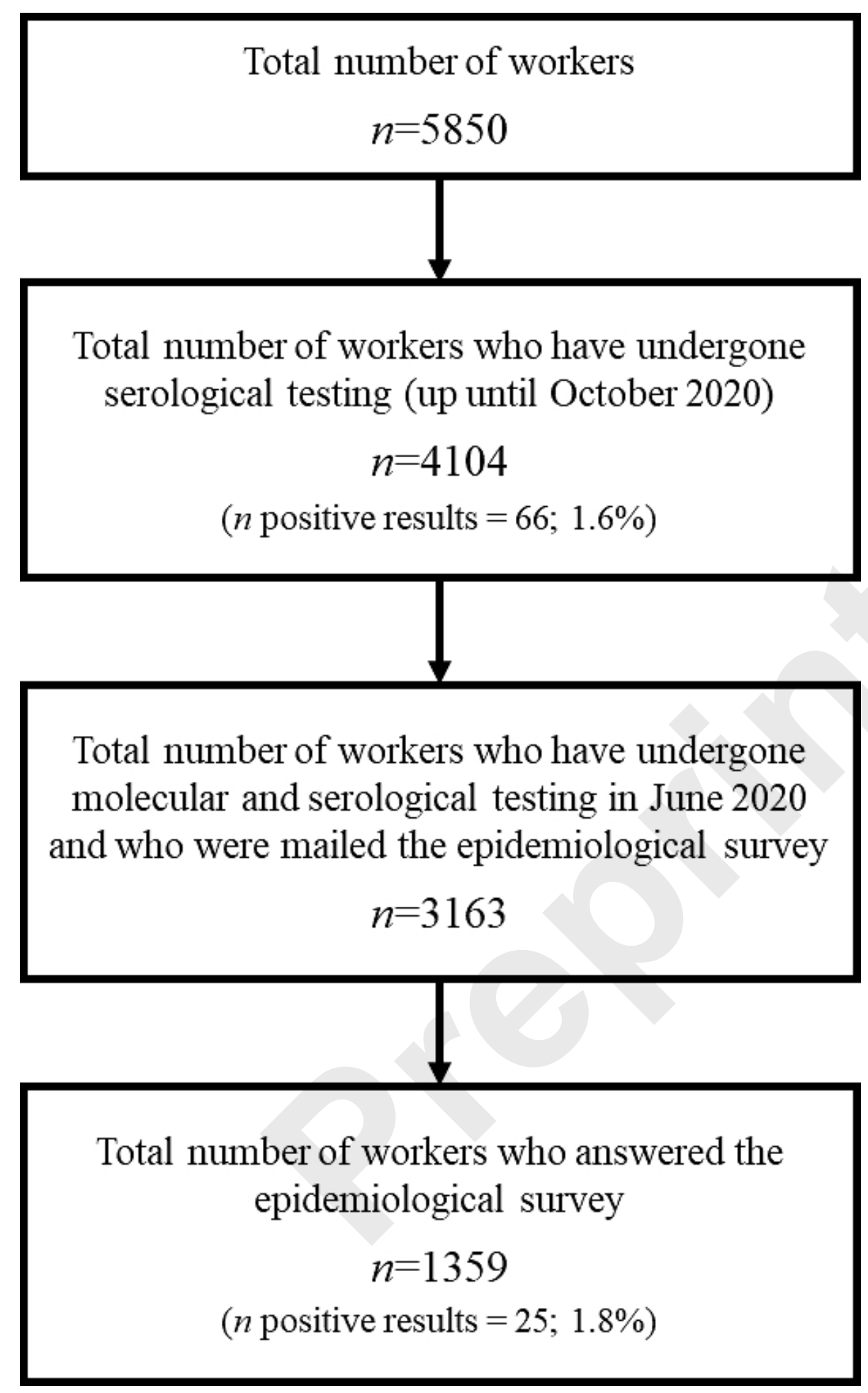


COVID-19 - Pandemic Management in EDP

Timeline - Summary

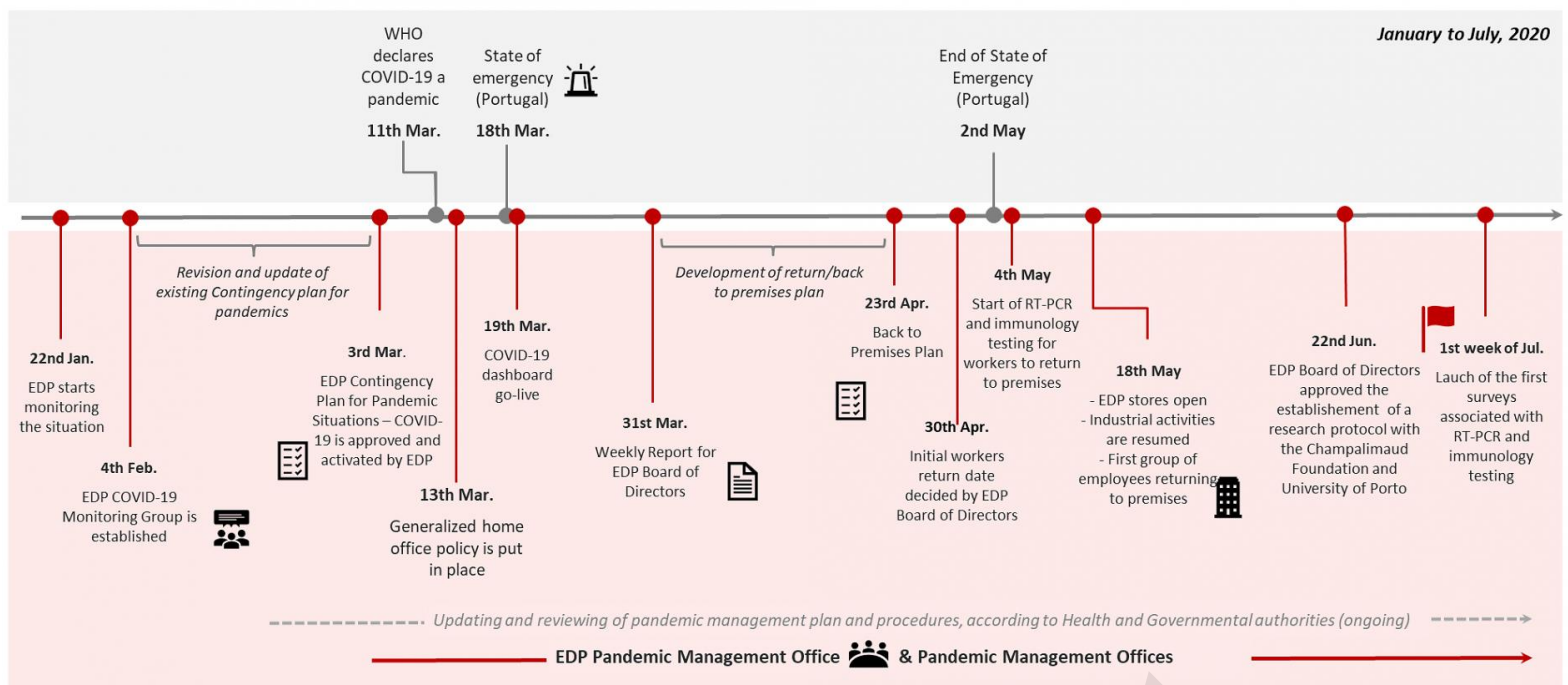

